\title{
Enhanced desorption of fluoxetine from polyethylene terephthalate microplastics in gastric fluid and sea water
}

\author{
Antony Wagstaff ${ }^{1} \cdot$ Bruce Petrie $^{1}$ D
}

Received: 30 December 2021 / Accepted: 27 January 2022 / Published online: 10 February 2022

(c) The Author(s) 2022

\begin{abstract}
There are concerns that microplastics act as a vector of pharmaceuticals in the aquatic environment. Most studies have focussed on pharmaceutical adsorption and have not investigated desorption in the various matrices that microplastics enter. Therefore we studied the desorption of the antidepressant drug fluoxetine from polyethylene terephthalate (PET) microplastics in river water, sea water, and simulated gastric and intestinal fluids. We found that most desorption occurred rapidly, within a few hours of exposure. Fluoxetine desorption fitted well to the Freundlich isotherm with $r^{2}$ values ranging from 0.97 to 0.99. Desorption decreased in the following order: gastric fluid at $20^{\circ} \mathrm{C}$ and $37{ }^{\circ} \mathrm{C}$; sea water at $20^{\circ} \mathrm{C}$; intestinal fluid at $20^{\circ} \mathrm{C}$ and $37^{\circ} \mathrm{C}$; then river water at $20^{\circ} \mathrm{C}$. The little difference in desorption in gastrointestinal fluids at $20^{\circ} \mathrm{C}$ and $37^{\circ} \mathrm{C}$ suggests a similar exposure risk to cold- and warm-blooded organisms following PET microplastic ingestion. Total desorption following sequential incubation $2 \mathrm{~h}$ in gastric fluid then $4 \mathrm{~h}$ in intestinal fluid to mimic gastrointestinal digestion was $37 \%$ at $20^{\circ} \mathrm{C}$ and $41 \%$ at $37{ }^{\circ} \mathrm{C}$. Interestingly, higher desorption of $18-23 \%$ occurred in sea water compared to river water, of $4-11 \%$. Under a worst-case scenario, more than $44 \mathrm{mg} \mathrm{kg}^{-1}$ body weight d $\mathrm{d}^{-1}$ or more than $52 \mathrm{mg} \mathrm{kg}^{-1}$ body weight d of PET microplastics from river water or sea water, respectively, need to be consumed to exceed the mammalian acceptable daily intake for fluoxetine. Further studies are needed on microplastic ingestion and the bioavailability of adsorbed pharmaceuticals to a range of exposed aquatic organisms.
\end{abstract}

Keywords Wastewater $\cdot$ Pollution $\cdot$ Plastic $\cdot$ Contaminant $\cdot$ Microplastic $\cdot$ Desorption

\section{Introduction}

Microplastics are plastic pieces smaller than $5 \mathrm{~mm}$ in all dimensions (Schmid et al. 2021; Dhaka et al. 2022). They pose a largely unknown risk to human and environmental health. There are concerns that microplastics act as a vector of other pollutants with known health effects such as persistent organic pollutants and heavy metals (Borges-Ramírez et al. 2021). A common pathway for microplastics to enter the environment is via wastewater discharges. Common microplastic polymer types found in wastewater include polyamide, polyethylene, and polyethylene terephthalate (PET) (Sun et al. 2019). In wastewater, these microplastics are present with a diverse range of pharmaceuticals that can adsorb to their surface (McDougall et al. 2021). Pharmaceuticals,

Bruce Petrie

b.r.petrie@rgu.ac.uk

1 School of Pharmacy and Life Sciences, Robert Gordon University, Aberdeen AB10 7GJ, UK by their very nature, can induce effects to exposed organisms once in the environment (Wang et al. 2021).

Previous research found low desorption of pharmaceuticals from polyamide and polyethylene microplastics in river water suggesting adsorbed pharmaceuticals can be transported for considerable distances (McDougall et al. 2021; Wagstaff et al. 2021). On the other hand, $>50 \%$ desorption of amitriptyline, amoxicillin, chlortetracycline, fluoxetine, propranolol, and tetracycline has been reported in simulated gastric fluids (Lin et al. 2020; Fan et al. 2021a; McDougall et al. 2021; Wagstaff et al. 2021). Liu et al (2020) found desorption of amlodipine and atorvastatin from polystyrene microplastics consisted of a fast desorption phase followed by a slow phase. This suggests pharmaceuticals adsorbed to microplastics pose a threat to exposed organisms. However, there is a paucity of information on desorption behaviour of pharmaceuticals in the variety of environments they enter (e.g., river water, sea water, gastric and intestinal fluids), particularly for some polymer types (e.g., PET). Desorption of pharmaceuticals can be evaluated by modelling 
desorption data to different isotherms (e.g., linear, Freundlich and Langmuir) (Song et al. 2021). These describe the relationship of adsorbate between the liquid phase and that adsorbed to the surface of the adsorbent.

The more hydrophobic cationic pharmaceuticals have been identified as contaminants of concern as they readily adsorb to microplastics in wastewater, and subsequently, desorb under low $\mathrm{pH}$ gastric conditions (McDougall et al. 2021). The antidepressant fluoxetine fits these criteria (Table S1) and alters the behaviour of various cold- and warm-blooded organisms including fish and birds (Whitlock et al. 2018; Hong et al. 2021). Therefore, it is essential to further understand the role microplastics can play in the exposure of organisms to potent pharmaceuticals such as fluoxetine. The objectives of the study were to, (i) investigate desorption kinetics of fluoxetine from PET microplastics in river water and sea water at $20^{\circ} \mathrm{C}$ and simulated gastric and intestinal fluids at $20^{\circ} \mathrm{C}$ and $37{ }^{\circ} \mathrm{C}$, (ii) establish desorption isotherms of fluoxetine in different matrices, and (iii) determine total fluoxetine desorption under simulated gastrointestinal digestion conditions of cold- and warm-blooded organisms.

\section{Materials and methods}

\section{Materials}

Standards of fluoxetine hydrochloride and carbamazepine (as internal standard) were purchased from Sigma Aldrich (Gillingham, UK). Sodium azide, sodium chloride $(\mathrm{NaCl})$, sodium taurocholate (98\%), bovine serum albumin ( $>98 \%$ ), and pepsin $\mathrm{A}\left(\geq 500 \mathrm{U} \mathrm{mg}^{-1}\right)$ were also obtained from Sigma Aldrich. High-performance liquid chromatography (HPLC) grade methanol, ammonium formate and formic acid, and GF/F glass fibre filter papers, $4 \mathrm{~mm}$ PVDF $0.45 \mu \mathrm{m}$ syringe filters, and hydrochloric acid $(\mathrm{HCl})$ were purchased from Fisher Scientific (Loughborough, UK). Ultrapure water was $18.2 \mathrm{M} \Omega \mathrm{cm}^{-1}$ quality. PET microplastics (maximum size $300 \mu \mathrm{m}$ ) were purchased from Goodfellow Cambridge Limited (Huntingdon, UK; Table S2). Municipal wastewater (25 L, pH 7.6) was collected from a septic tank in NorthEast Scotland during July 2021 and frozen at $-20^{\circ} \mathrm{C}$. The wastewater did not contain detectable levels of fluoxetine or carbamazepine. Non-tidal river water (2.5 L, $\mathrm{pH} 7.6)$ and sea water $(2.5 \mathrm{~L}, 32.2$ practical salinity units, $\mathrm{pH} 7.7)$ were collected and frozen at $-20^{\circ} \mathrm{C}$.

\section{Adsorption experiments}

Adsorption experiments were conducted in wastewater. Wastewater was defrosted, filtered through GF/F filters, and treated with sodium azide $\left(0.2 \mathrm{~g} \mathrm{~L}^{-1}\right)$ to limit microbial activity. PET microplastics $\left(2.5 \mathrm{~g} \mathrm{~L}^{-1}\right)$ in $20 \mathrm{~mL}$ wastewater were prepared in $50 \mathrm{~mL}$ borosilicate flasks. These were mixed at $220 \mathrm{rpm}$ using a MaxQ 4000 orbital shaker (Thermo Scientific, Loughborough, UK) and kept in the dark by wrapping flasks in aluminium foil. A fluoxetine concentration of $15 \mathrm{mg} \mathrm{L}^{-1}$ was used to establish uptake kinetics. Samples were collected at 0.1, 0.2, 0.3, 0.5, 1, 2, 3, 4, 5, 6,24 , and $48 \mathrm{~h}$. The uptake kinetics were fitted using the pseudo-second-order model (Eq. 1):

$\frac{t}{q_{t}^{a}}=\left(\frac{1}{k\left(q_{e}^{a 2}\right)}\right)+\left(\frac{1}{q_{e}^{a}}\right) t$

where $q_{t}^{a}$ and $q_{e}{ }^{a}$ are the adsorbed fluoxetine concentrations $\left(\mathrm{mg} \mathrm{kg}^{-1}\right)$ at any time and under equilibrium, $t$ (hours) is the mixing time and $k\left(\mathrm{~kg} \mathrm{mg}^{-1} \mathrm{~h}^{-1}\right)$ is the equilibrium rate constant.

Fluoxetine concentrations of $1,2.5,5,10$, and $15 \mathrm{mg} \mathrm{L}^{-1}$ were used to determine adsorption isotherms. Samples were mixed for $24 \mathrm{~h}$ before collection. The linear (Eq. 2), Freundlich (Eq. 3) and Langmuir isotherms (Eq. 4) were used to model the data:

$q_{e}^{a}=K_{d} C_{e}$

$q_{e}^{a}=K_{F} C_{e}^{1 / n}$

$q_{e}^{a}=\frac{q_{\max } K_{L} C_{e}}{1+K_{L} C_{e}}$

$C_{e}\left(\mathrm{mg} \mathrm{L}^{-1}\right)$ is the liquid phase concentration of fluoxetine, $K_{d}\left(\mathrm{~L} \mathrm{~kg}^{-1}\right)$ is the distribution coefficient between the microplastic and wastewater, $K_{F}\left[\left(\mathrm{mg} \mathrm{kg}^{-1}\right)\left(\mathrm{mg} \mathrm{L}^{-1}\right)^{1 / n}\right]$ and $n$ are the Freundlich constants. $Q_{\max }\left(\mathrm{mg} \mathrm{kg}^{-1}\right)$ is the estimated maximum adsorption capacity and $K_{L}\left(\mathrm{~L} \mathrm{mg}^{-1}\right)$ is the Langmuir constant.

\section{Desorption experiments}

To determine desorption kinetics, adsorption was initially performed at a fluoxetine concentration in wastewater of $15 \mathrm{mg} \mathrm{L}^{-1}$ (as described in the section "Adsorption experiments"). Following $24 \mathrm{~h}$ of mixing, PET microplastics were collected and transferred into $20 \mathrm{~mL}$ of desorption solution. The different desorption solutions investigated were filtered river water at $20{ }^{\circ} \mathrm{C}(\mathrm{pH} 7.6)$, filtered sea water at $20^{\circ} \mathrm{C}(\mathrm{pH}$ 7.7), gastric fluids at $20^{\circ} \mathrm{C}$ and $37^{\circ} \mathrm{C}(\mathrm{pH} 2.0)$, and intestinal fluids at $20^{\circ} \mathrm{C}$ and $37^{\circ} \mathrm{C}(\mathrm{pH} \mathrm{7.0)}$. Gastric and intestinal fluids were prepared as described in Liu et al. (2020). Gastric fluid comprised $3.2 \mathrm{~g} \mathrm{~L}^{-1}$ pepsin A in $100 \mathrm{mM}$ $\mathrm{NaCl}$ and adjusted to $\mathrm{pH} 2$ using $\mathrm{HCl}$. Intestinal fluid comprised $5 \mathrm{~g} \mathrm{~L}^{-1}$ bovine serum albumin and $10 \mathrm{mM}$ sodium 
taurocholate in $100 \mathrm{mM} \mathrm{NaCl}$. Samples were collected at $0.1,0.2,0.3,0.7,1,2,4,6,24$, and $48 \mathrm{~h}$. Desorption kinetics were determined using Eq. $1\left(q_{e}{ }^{a}\right.$ and $q_{t}^{a}$ were replaced with $q_{e}{ }^{d}$ and $q_{t}{ }^{d}$, respectively, which represents the desorbed fluoxetine concentration from the microplastics, $\mathrm{mg} \mathrm{kg}^{-1}$, and the desorbed concentration at time $t$ ).

Desorption isotherms were prepared by first undertaking adsorption of fluoxetine at $1,2.5,5,10$, and $15 \mathrm{mg} \mathrm{L}^{-1}$ in wastewater (as described in the section "Adsorption experiments"). Microplastics were collected and transferred to different desorption solutions (river water at $20^{\circ} \mathrm{C}$, sea water at $20^{\circ} \mathrm{C}$, and gastric and intestinal fluids at $20^{\circ} \mathrm{C}$ and $37^{\circ} \mathrm{C}$ ), then collected after $24 \mathrm{~h}$ mixing. Linear, Freundlich and Langmuir isotherms (Eqs. 2-4) were used to model the data. Sequential incubation of microplastics (previously adsorbed with fluoxetine in wastewater at $15 \mathrm{mg} \mathrm{L}^{-1}$ ) for $2 \mathrm{~h}$ in gastric fluids then $4 \mathrm{~h}$ in intestinal fluids was undertaken to mimic gastrointestinal digestion at $20{ }^{\circ} \mathrm{C}$ and $37{ }^{\circ} \mathrm{C}$ (Wang et al. 2011).

\section{Analysis methods}

All experiments were prepared in triplicate. Flasks were also prepared without microplastic to ensure no losses of fluoxetine to glassware surfaces. Upon collection, samples were passed through $0.45 \mu \mathrm{m}$ PVDF filters (Wagstaff et al. 2021) and spiked with $1 \mathrm{mg} \mathrm{L}^{-1}$ of carbamazepine as internal standard and analysed within $24 \mathrm{~h}$. Fluoxetine quantitation was performed using an Agilent 1260 Infinity Series HPLC and a 6420 triple quadrupole mass spectrometer in positive ionisation mode. A $100 \times 2.1 \mathrm{~mm}$ Kinetex $5 \mu \mathrm{m}$ C18 column (Phenomenex, Cheshire, UK) was used with a mobile phase gradient elution at $0.35 \mathrm{~mL} \mathrm{~min}^{-1}$ of $10 \mathrm{mM}$ ammonium formate and $0.1 \%$ formic acid in water and methanol (see Table S3 for details). The column temperature was $40{ }^{\circ} \mathrm{C}$ and the injection volume was $2 \mu \mathrm{L}$. The MRM transitions monitored were $309.8>44.0 \mathrm{~m} / \mathrm{z}$ and $309.8>147.7 \mathrm{~m} / \mathrm{z}$ for fluoxetine and $236.8>193.9 \mathrm{~m} / \mathrm{z}$ for carbamazepine. The quantitation limit of the method was $0.01 \mathrm{mg} \mathrm{L}^{-1}$. Zeta potential measurements of the PET microplastics in different matrices were made using a Zetasizer Nano ZS (Malvern Panalytical, Malvern, UK).

\section{Results and discussion}

\section{Fluoxetine adsorption to polyethylene terephthalate microplastics in wastewater}

Initially, the adsorption of fluoxetine to polyethylene terephthalate (PET) microplastics in wastewater was investigated. It was established that adsorption equilibrium was reached within a few hours (Figure S1). This is significant as it is within the typical wastewater retention time of sewer systems (Petrie et al. 2019). The data fitted the pseudo-second-order kinetic model with a coefficient of determination $\left(r^{2}\right)$ of 0.999 and a $k$ value of $0.003 \mathrm{~kg} \mathrm{mg}^{-1} \mathrm{~h}^{-1}$. The calculated $q_{e}$ value was $1817 \mathrm{mg} \mathrm{kg}^{-1}$ which compared well to the experimental $q_{e}$ value (Figure S1). All subsequent samples used to establish adsorption isotherms as well as those microplastics utilised in desorption studies were collected after $24 \mathrm{~h}$ mixing to ensure equilibrium conditions were established. The Freundlich isotherm was most suited to model the adsorption data with an $r^{2}$ value of 0.989 and a $K_{F}$ value of $548\left(\mathrm{mg} \mathrm{kg}^{-1}\right)\left(\mathrm{mg} \mathrm{L}^{-1}\right)^{1 / n}$ (Table S1; Figure S4). This suggests a multilayer adsorption of fluoxetine to the microplastics surface (Fan et al. 2021b). Fluoxetine is present as the cationic species in the wastewater $(\mathrm{pH}$ 7.6) and electrostatic interactions with the negatively charged microplastic surface as well as hydrophobic interactions are considered important for adsorption (Wagstaff et al. 2021). The observations made on fluoxetine adsorption to PET microplastics agree with previous studies on fluoxetine adsorption to polyethylene and polyamide microplastics in wastewater (McDougall et al. 2021; Wagstaff et al. 2021), as well as other drugs to various microplastic polymer types in water (Razanajatovo et al. 2018; Puckowski et al. 2021).

\section{Desorption kinetics and isotherms in different matrices}

Desorption kinetics were investigated in different matrices at an average adsorbed fluoxetine concentration to PET microplastics of $1795 \pm 127 \mathrm{mg} \mathrm{kg}^{-1}$. Desorption occurred rapidly in all matrices studied and equilibrium appeared to be reached within a few hours (Fig. 1). Previous research has found a rapid desorption phase of pharmaceuticals from microplastics in gastric fluids, intestinal fluids and sea water which is completed in two hours (Liu et al. 2020). Rapid desorption is significant considering that retention within gastric or intestinal fluids of exposed organisms may only be a few hours. Fluoxetine desorption fitted the pseudo-second order kinetic model with $r^{2}$ values in the range $0.994-1.00$ (Table 1). Desorption $k$ values ranged from $7.82 \times 10^{-3} \mathrm{~kg} \mathrm{mg}^{-1} \mathrm{~h}^{-1}$ in gastric fluid at $20{ }^{\circ} \mathrm{C}$ to $3.14 \times 10^{-2} \mathrm{~kg} \mathrm{mg}^{-1} \mathrm{~h}^{-1}$ in gastric fluid at $37{ }^{\circ} \mathrm{C}$. Both the calculated and experimental desorbed fluoxetine concentrations were compared well (Fig. 1, Table 1). The calculated $q_{e}{ }^{d}$ ranged from $163 \mathrm{mg} \mathrm{kg}^{-1}$ in river water at $20{ }^{\circ} \mathrm{C}$ to $566 \mathrm{mg} \mathrm{kg}^{-1}$ in gastric fluid at $37^{\circ} \mathrm{C}$.

The desorption data was modelled using the Linear $\left(r^{2}\right.$ ranged from 0.813 to 0.997$)$, Freundlich ( $r^{2}$ ranged from 0.977 to 0.999 ), and Langmuir isotherms ( $r^{2}$ ranged from 0.956 to 0.999 ) (Table 1 , Fig. 2). The $K_{F}$ values derived from the Freundlich isotherms ranged from 905 to $2.37 \times 10^{3}$ $\left(\mathrm{mg} \mathrm{kg}^{-1}\right)\left(\mathrm{mg} \mathrm{L}^{-1}\right)^{1 / n}$ and followed: gastric fluid at 
Fig. 1 Desorbed fluoxetine concentrations $\left(\mathrm{mg} \mathrm{kg}^{-1}\right)$ from polyethylene terephthalate (PET) microplastics in river water at $20^{\circ} \mathrm{C}(\mathbf{a})$, sea water at $20{ }^{\circ} \mathrm{C}$ (b), gastric fluid at $20^{\circ} \mathrm{C}$ (c), gastric fluid at $37^{\circ} \mathrm{C}(\mathbf{d})$, intestinal fluid at $20^{\circ} \mathrm{C}(\mathbf{e})$, and intestinal fluid at $37^{\circ} \mathrm{C}$ (f). Data is fitted using the pseudosecond-order kinetics model. All graphs have the same axis scales to enable direct comparisons between different matrices (a)

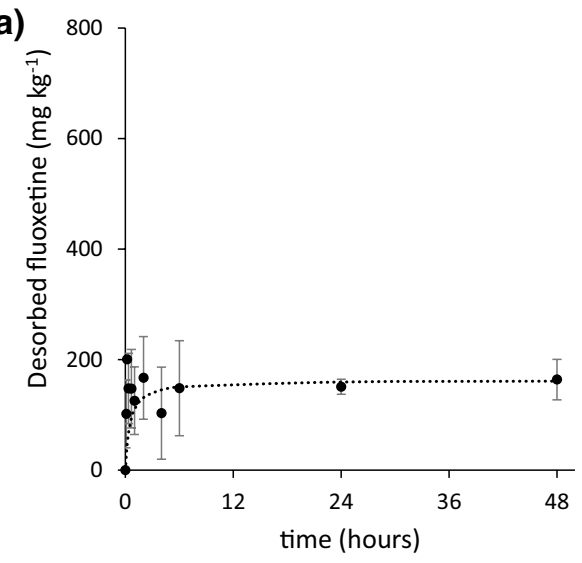

(c)

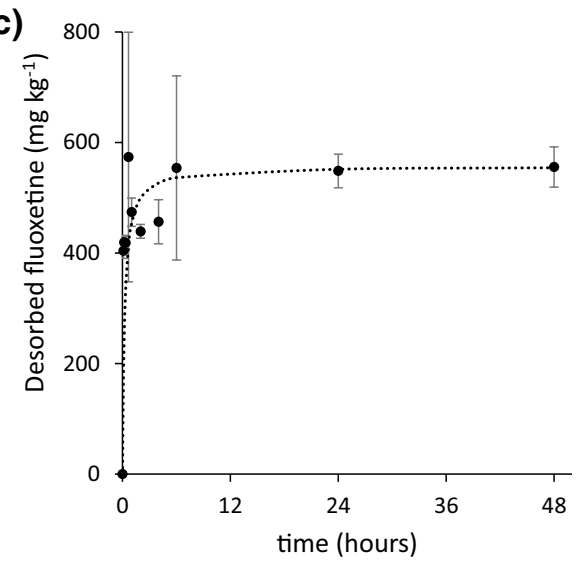

(e)

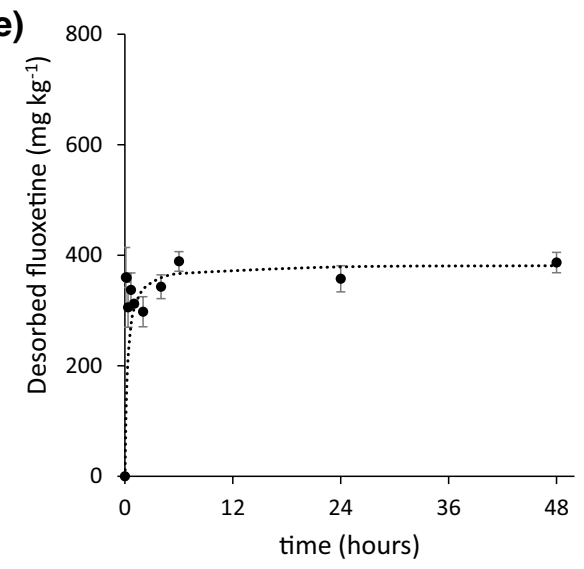

(b)

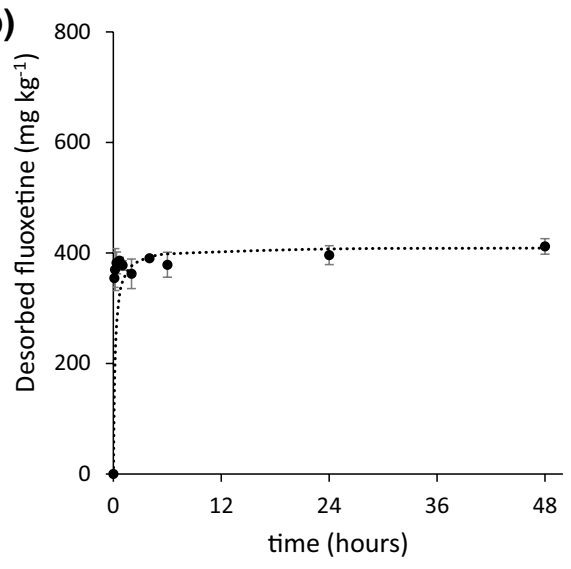

(d)

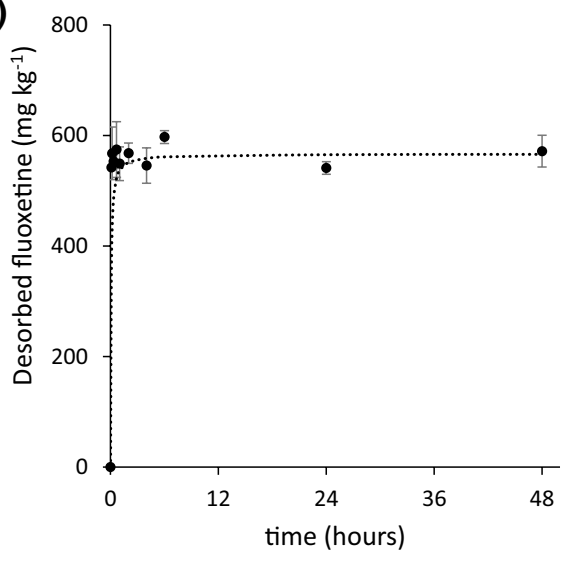

(f)

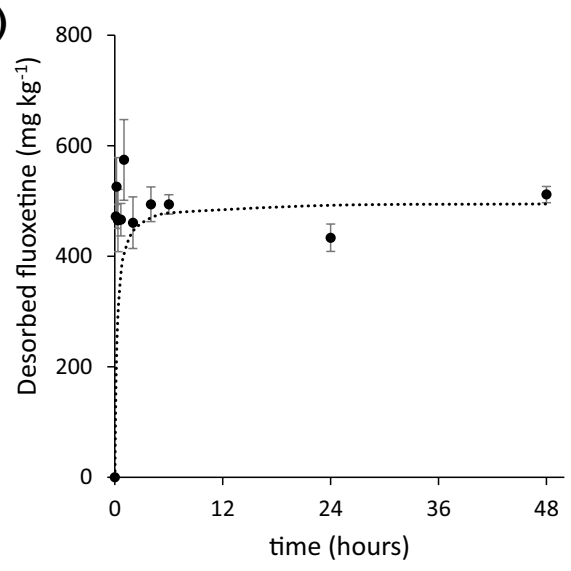

$20{ }^{\circ} \mathrm{C} \approx$ gastric fluid at $37{ }^{\circ} \mathrm{C}<$ sea water at $20{ }^{\circ} \mathrm{C}<$ intestinal fluid at $37^{\circ} \mathrm{C} \approx$ intestinal fluid at $20^{\circ} \mathrm{C}<$ river water at $20{ }^{\circ} \mathrm{C}$ (Table 1). Previous research found increased desorption of fluoxetine from polyethylene microplastics in gastric fluids compared to intestinal fluids and river water (McDougall et al. 2021). Interestingly, desorption in sea water was greater than both river water and intestinal fluids. The zeta potential of the PET microplastics in sea water, river water and intestinal fluids was $-2.3 \mathrm{mV},-19.3 \mathrm{mV}$ and $-8.8 \mathrm{mV}$, respectively (Table $\mathrm{S} 2$ ). The low zeta potential in sea water is attributed to the high concentration of $\mathrm{Na}^{+}$ions which can have a charge shielding effect on the microplastic surface. This suggests electrostatic interactions are important for fluoxetine adsorption. The zeta potential in sea water is similar to polyethylene microplastics in the same matrix $(-1.8 \mathrm{mV})$ (Tziourrou et al. 2020).

Fluoxetine desorption in river water varied from 4 to $11 \%$ across the adsorbed concentration range studied. This indicates the potential for considerable transport of fluoxetine adsorbed to PET microplastics in rivers. The increased desorption in sea water (18-23\%) suggests a lower risk posed by fluoxetine adsorbed to PET 
Table 1 Kinetics and isotherm data for desorption of fluoxetine from polyethylene terephthalate (PET) microplastics

\begin{tabular}{|c|c|c|c|c|c|c|c|c|}
\hline \multirow[t]{2}{*}{ Model } & \multirow[t]{2}{*}{ Type } & \multirow[t]{2}{*}{ Parameter } & \multicolumn{6}{|c|}{ Desorption matrix } \\
\hline & & & $\begin{array}{l}\text { River water at } \\
20{ }^{\circ} \mathrm{C}\end{array}$ & $\begin{array}{l}\text { Sea water at } \\
20^{\circ} \mathrm{C}\end{array}$ & $\begin{array}{l}\text { Gastric fluid at } \\
20^{\circ} \mathrm{C}\end{array}$ & $\begin{array}{l}\text { Gastric fluid at } \\
37^{\circ} \mathrm{C}\end{array}$ & $\begin{array}{l}\text { Intestinal } \\
\text { fluid at } \\
20^{\circ} \mathrm{C}\end{array}$ & $\begin{array}{l}\text { Intestinal } \\
\text { fluid at } \\
37^{\circ} \mathrm{C}\end{array}$ \\
\hline \multirow[t]{3}{*}{ Kinetics } & \multirow[t]{3}{*}{$\begin{array}{l}\text { Pseudo-second } \\
\text { order }\end{array}$} & $q_{e}^{d}\left(\mathrm{mg} \mathrm{kg}^{-1}\right)$ & 163 & 410 & 557 & 566 & 383 & 497 \\
\hline & & $k\left(\mathrm{~kg} \mathrm{mg}^{-1} \mathrm{~h}^{-1}\right)$ & $1.28 \times 10^{-2}$ & $1.35 \times 10^{-2}$ & $7.82 \times 10^{-3}$ & $3.14 \times 10^{-2}$ & $9.80 \times 10^{-3}$ & $8.65 \times 10^{-3}$ \\
\hline & & $r^{2}$ & 0.997 & 1.00 & 1.00 & 0.999 & 0.999 & 0.994 \\
\hline \multirow[t]{8}{*}{ Isotherm } & \multirow[t]{2}{*}{ Linear } & $K_{d}\left(\mathrm{~L} \mathrm{~kg}^{-1}\right)$ & $2.50 \times 10^{3}$ & $1.25 \times 10^{3}$ & 900 & $1.02 \times 10^{3}$ & $1.43 \times 10^{3}$ & $1.52 \times 10^{3}$ \\
\hline & & $r^{2}$ & 0.813 & 0.985 & 0.992 & 0.959 & 0.902 & 0.997 \\
\hline & \multirow[t]{3}{*}{ Freundlich } & $\begin{array}{r}K_{F}\left[\left(\mathrm{mg} \mathrm{kg}^{-1}\right)\right. \\
\left.\left(\mathrm{mg} \mathrm{L}^{-1}\right)^{1 / n}\right]\end{array}$ & $2.37 \times 10^{3}$ & $1.35 \times 10^{3}$ & 905 & $1.06 \times 10^{3}$ & $1.64 \times 10^{3}$ & $1.53 \times 10^{3}$ \\
\hline & & $N$ & 1.92 & 1.26 & 1.00 & 1.08 & 2.03 & 1.06 \\
\hline & & $r^{2}$ & 0.977 & 0.999 & 0.998 & 0.991 & 0.995 & 0.999 \\
\hline & \multirow[t]{3}{*}{ Langmuir } & $q_{\max }\left(\mathrm{mg} \mathrm{kg}^{-1}\right)$ & $2.29 \times 10^{3}$ & $4.07 \times 10^{3}$ & $21.8 \times 10^{3}$ & $9.15 \times 10^{3}$ & $2.06 \times 10^{3}$ & $1.59 \times 10^{4}$ \\
\hline & & $K_{L}\left(\mathrm{~L} \mathrm{mg}^{-1}\right)$ & 4.84 & 0.491 & $4.33 \times 10^{-2}$ & 0.131 & 2.96 & 0.106 \\
\hline & & $r^{2}$ & 0.956 & 0.999 & 0.991 & 0.962 & 0.979 & 0.998 \\
\hline
\end{tabular}

microplastics compared to rivers (with zero salinity). Consideration must also be given for the potential of increasing desorption as microplastics disperse in the environment, assuming they are transported (diluted) into waters with reduced dissolved fluoxetine concentrations. Liu et al. (2019) found bisphenol-A desorbed from various microplastics in three consecutive desorption 'cycles' where the microplastics were introduced into a fresh matrix (ultrapure water and sea water) with no dissolved analyte present. However, increased organism exposure to 'free' fluoxetine in this case also needs to be considered.

Interestingly, there was little difference in desorption of fluoxetine in gastrointestinal fluids at $20{ }^{\circ} \mathrm{C}$ and $37^{\circ} \mathrm{C}$ (Table 1). This suggests there is a similar exposure risk of fluoxetine desorption from PET microplastics at warm-blooded over cold-blooded temperatures. Previous desorption studies of fluoxetine from polyethylene microplastics in gastric and intestinal fluids showed little difference between 20 and $37^{\circ} \mathrm{C}$ (McDougall et al. 2021). On the other hand, increased desorption of fluoxetine was observed from polyamide microplastics in gastric fluids at $37{ }^{\circ} \mathrm{C}$ over $20^{\circ} \mathrm{C}$ (Wagstaff et al. 2021). However, in both these studies, only one adsorbed fluoxetine concentration was investigated. Greater desorption of fluoxetine from PET microplastics in gastric fluids over the other matrices studied can be attributed to the low $\mathrm{pH}$ conditions reducing the surface charge of the microplastic and the electrostatic interaction with the protonated fluoxetine (Wagstaff et al. 2021), as well as the solubilisation of fluoxetine by pepsin (Liu et al. 2020).

\section{Environmental significance}

PET microplastics with adsorbed fluoxetine $\left(1722 \pm 120 \mathrm{mg} \mathrm{kg}^{-1}\right)$ were exposed to gastric fluids for $2 \mathrm{~h}$ then intestinal fluids for $4 \mathrm{~h}$ to mimic typical retention within the gastrointestinal tract (Wang et al. 2011). The total desorption between cold- and warm-blooded temperatures was similar ( $37 \pm 3 \%$ versus $41 \pm 2 \%$ ) (Fig. 3 ). At $20{ }^{\circ} \mathrm{C}, 30 \%$ desorption occurred in gastric fluid and $7 \%$ in intestinal fluid. While at $37^{\circ} \mathrm{C}$ the desorption was $31 \%$ (gastric fluid) and $10 \%$ (intestinal fluid). However, the difference in total desorption at the two different temperatures was insignificant ( $p$-value $>0.05)$. The findings observed are similar to those from the desorption isotherm (following $24 \mathrm{~h}$ mixing) as the desorption process was rapid (Fig. 1). Amlodipine, a cationic drug with similar hydrophobicity to fluoxetine, exhibited desorption in the range $27-39 \%$ from polystyrene microplastics under similar experimental conditions (Liu et al. 2020). However, statistically higher desorption occurred at warm-blooded temperature $\left(37^{\circ} \mathrm{C}\right)$ compared to cold-blooded temperature $\left(18^{\circ} \mathrm{C}\right)$.

To determine the quantity of PET microplastics that need to be ingested $\left(\mathrm{MP}_{\mathrm{ING}}\right)$ to exceed the fluoxetine acceptable daily intake (ADI) Eq. (5) was used:

$\mathrm{MP}_{\mathrm{ING}}=\frac{\mathrm{ADI}}{\left(\mathrm{MP}_{\mathrm{Flu}} \times \frac{(100-\text { Des })}{100}\right)}$

$A D I$ is acceptable daily intake of fluoxetine $\left(9.7 \times 10^{-4} \mathrm{mg} \mathrm{kg}^{-1}\right.$ body weight $\left.\mathrm{d}^{-1}\right)$ obtained from Bruce 
Fig. 2 Desorption isotherms of fluoxetine from polyethylene terephthalate (PET) microplastics in river water at $20^{\circ} \mathrm{C}(\mathbf{a})$, sea water at $20{ }^{\circ} \mathrm{C}(\mathbf{b})$, gastric fluid at $20^{\circ} \mathrm{C}(\mathbf{c})$, gastric fluid at $37^{\circ} \mathrm{C}(\mathbf{d})$, intestinal fluid at $20^{\circ} \mathrm{C}(\mathbf{e})$, and intestinal fluid at $37{ }^{\circ} \mathrm{C}(\mathbf{f})$. The experimental data are fitted to the Linear, Freundlich and Langmuir isotherms. All graphs have the same axis scales to enable direct comparisons between different matrices (a)

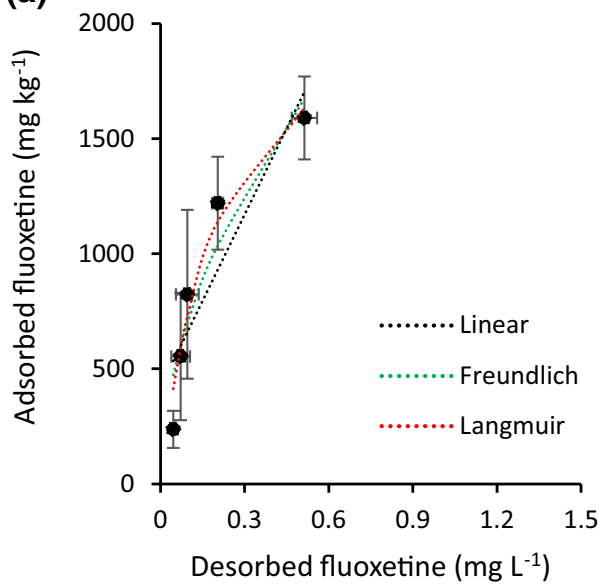

(c)

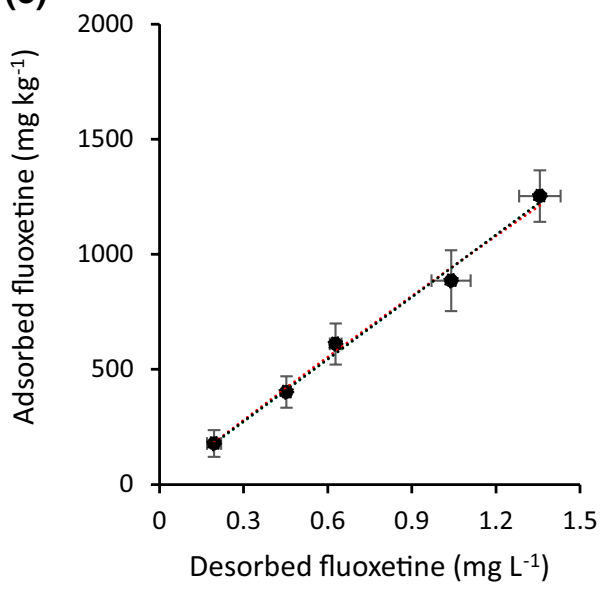

(e)

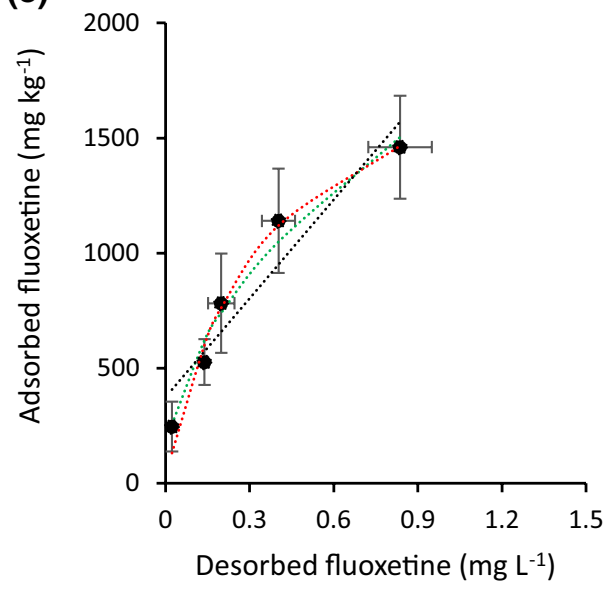

(b)

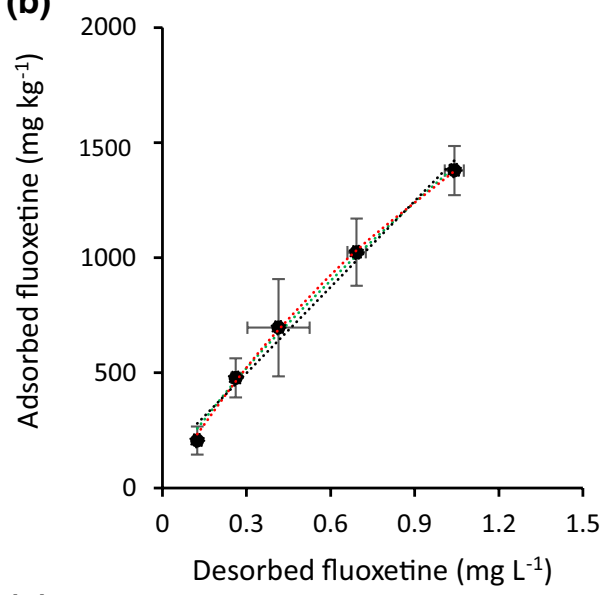

(d)

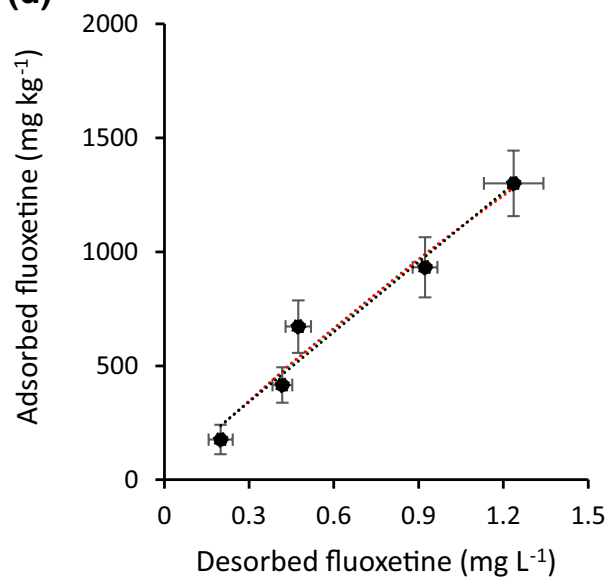

(f)

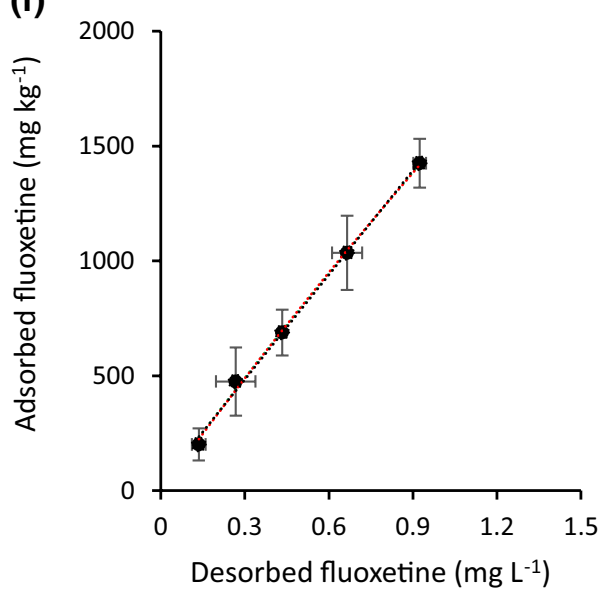

et al (2010) and was derived from mammalian studies. This is the exposure level not likely to be associated with adverse health effects due to chronic exposure. $M P_{F l u}$ is the fluoxetine concentration adsorbed on PET microplastics $\left(23.5 \mathrm{mg} \mathrm{kg}^{-1}\right)$. This was determined using Eq. (3) and the highest reported fluoxetine concentration in wastewater $\left(1.3 \times 10^{-3} \mathrm{mg} \mathrm{L}^{-1}\right.$ Bean et al. 2017) to represent a worst-case scenario. Des is the average desorption value in river water (7\%) or sea water (20\%). The quantity of PET microplastics that would need to be consumed to pose a risk are $>44$ and $>52 \mathrm{mg} \mathrm{kg}^{-1}$ body weight $\mathrm{d}^{-1}$ for fresh water and marine water organisms, respectively. It should be made clear that such calculations have considerable limitations and uncertainties but do give an indication of the microplastic quantities that need to be consumed to pose a potential problem with respect to adsorbed fluoxetine. It is also 


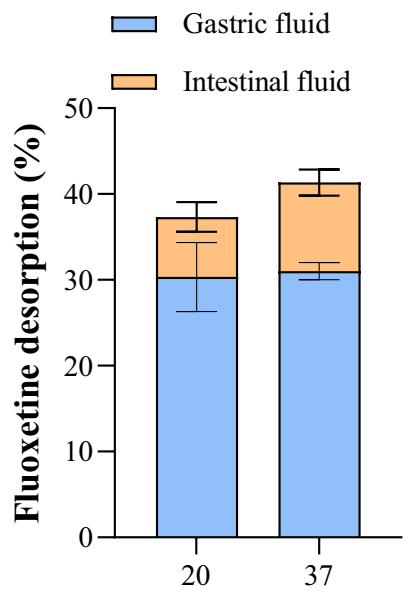

Temperature $\left({ }^{\circ} \mathrm{C}\right)$

Fig. 3 Desorption of fluoxetine (\%) from polyethylene terephthalate (PET) microplastics under gastrointestinal conditions comprising $2 \mathrm{~h}$ exposure time in gastric fluids followed by $4 \mathrm{~h}$ exposure in intestinal fluids. Desorption in intestinal fluids represents the desorption percentage of the original adsorbed fluoxetine concentration

important to consider that this is only one exposure route and organisms can also be exposed to dissolved fluoxetine in water and from fluoxetine within the tissues of prey species.

\section{Conclusion}

The desorption of fluoxetine from PET microplastics occurred rapidly in the different matrices studied. Most fluoxetine desorption occurred within a few hours. Desorption data fitted well to the Freundlich isotherm with $r^{2}$ values in the range 0.977-0.999. Greater desorption occurred in the low $\mathrm{pH}$ gastric fluids. The $K_{F}$ values followed: gastric fluid at $20{ }^{\circ} \mathrm{C} \approx$ gastric fluid at $37^{\circ} \mathrm{C}<$ sea water at $20^{\circ} \mathrm{C}<$ intestinal fluid at $37{ }^{\circ} \mathrm{C} \approx$ intestinal fluid at $20^{\circ} \mathrm{C}<$ river water at $20^{\circ} \mathrm{C}$. Interestingly, there was little difference in desorption between cold- and warm-blooded temperatures. Under a worst-case scenario, $>44$ (river water) or $>52 \mathrm{mg} \mathrm{kg}^{-1}$ body weight $\mathrm{d}^{-1}$ (sea water) of PET microplastics would need to be consumed to exceed the ADI for fluoxetine.

Supplementary Information The online version contains supplementary material available at https://doi.org/10.1007/s10311-022-01405-0.

Acknowledgements Support by the Royal Society of Edinburgh is greatly appreciated. AW is grateful to the Carnegie Trust for the Universities of Scotland for the award of a vacation scholarship.

Authors' contribution Both authors contributed to the study conception and design. Analysis and data collection were performed by AW. The first draft of the manuscript was written by AW and reviewed by BP. Both authors read and approved the final manuscript.

\section{Declarations}

Conflict of interest The authors have no relevant financial or non-financial interests to disclose.

Open Access This article is licensed under a Creative Commons Attribution 4.0 International License, which permits use, sharing, adaptation, distribution and reproduction in any medium or format, as long as you give appropriate credit to the original author(s) and the source, provide a link to the Creative Commons licence, and indicate if changes were made. The images or other third party material in this article are included in the article's Creative Commons licence, unless indicated otherwise in a credit line to the material. If material is not included in the article's Creative Commons licence and your intended use is not permitted by statutory regulation or exceeds the permitted use, you will need to obtain permission directly from the copyright holder. To view a copy of this licence, visit http://creativecommons.org/licenses/by/4.0/.

\section{References}

Bean TG, Arnold KE, Lane JM, Bergström E, Thomas-Oates J, Rattner BA, Boxall ABA (2017) Predictive framework for estimating exposure of birds to pharmaceuticals. Environ Toxicol Chem 36(9):2335-2344. https://doi.org/10.1002/etc.3771

Borges-Ramírez MM, Escalona-Segura G, Huerta-Lwanga E, IñigoElias E, Osten JR-V (2021) Organochlorine pesticides, polycyclic aromatic hydrocarbons, metals and metalloids in microplastics found in regurgitated pellets of black vulture from Campeche, Mexico. Sci Total Environ 801:149674. https://doi.org/10.1016/j. scitotenv.2021.149674

Bruce GM, Pleus RC, Snyder SA (2010) Toxicological relevance of pharmaceuticals in drinking water. Environ Sci Technol 44(14):5619-5626. https://doi.org/10.1021/es1004895

Dhaka V, Singh S, Anil AG, Sunil Kumar Naik TS, Garg S, Samuel J, Kumar M, Ramamurthy PC, Singh J (2022) Occurrence, toxicity and remediation of polyethylene terephthalate plastics. A review. Environ Chem Lett. https://doi.org/10.1007/s10311-021-01384-8

Fan X, Gan R, Liu J, Xie Y, Xu D, Xiang Y, Su J, Teng Z, Hou J (2021a) Adsorption and desorption behaviors of antibiotics by tire wear particles and polyethylene microplastics with or without aging processes. Sci Total Environ 771:145451. https://doi.org/ 10.1016/j.scitotenv.2021.145451

Fan X, Zou Y, Geng N, Liu J, Hou J, Li D, Yang C, Li Y (2021b) Investigation on the adsorption and desorption behaviors of antibiotics by degradable MPs with or without UV ageing process. J Hazard Mater 401:123363. https://doi.org/10.1016/j.jhazmat.2020.123363

Hong X, Zhao G, Zhou Y, Chen R, Li J, Zha J (2021) Risks to aquatic environments posed by 14 pharmaceuticals as illustrated by their effects on zebrafish behaviour. Sci Total Environ 771:145450. https://doi.org/10.1016/j.scitotenv.2021.145450

Lin L, Tang S, Wang XS, Sun X, Han Z, Chen Y (2020) Accumulation mechanism of tetracycline hydrochloride from aqueous solutions by nylon microplastics. Environ Technol Innov 18:100750. https:// doi.org/10.1016/j.eti.2020.100750

Liu X, Shi H, Xie B, Dionysiou, DD, Zhao Y (2019) Microplastics as both a sink and a source of bisphenol $\mathrm{A}$ in the marine environment. Environ Sci Technol 53(17):10188-10196. https://doi.org/ 10.1021/acs.est.9b02834

Liu P, Wu X, Liu H, Wang H, Lu K, Gao S (2020) Desorption of pharmaceuticals from pristine and aged polystyrene microplastics under simulated gastrointestinal conditions. J Hazard Mater 392:122346. https://doi.org/10.1016/j.jhazmat.2020.122346 
McDougall L, Thomson L, Brand R, Wagstaff A, Lawton LA, Petrie B (2021) Adsorption of a diverse range of pharmaceuticals to polyethylene microplastics in wastewater and their desorption in environmental matrices. Sci Total Environ 808:152071. https:// doi.org/10.1016/j.scitotenv.2021.152071

Petrie B, Lopardo L, Proctor K, Youdan J, Barden R, KasprzykHordern B (2019) Assessment of bisphenol-A in the urban water cycle. Sci Total Environ 650:900-907. https://doi.org/10.1016/j. scitotenv.2018.09.011

Puckowski A, Cwięk W, Mioduszewska K, Stepnowski P, BiałkBielińska A (2021) Sorption of pharmaceuticals on the surface of microplastics. Chemosphere 263:127976. https://doi.org/10. 1016/j.chemosphere.2020.127976

Razanajatovo RM, Ding J, Zhang S, Jiang H, Zou H (2018) Sorption and desorption of selected pharmaceuticals by polyethylene microplastics. Mar Pollut Bull 136:516-523. https://doi.org/10. 1016/j.marpolbul.2018.09.048

Schmid C, Cozzarini L, Zambello E (2021) Microplastic's story. Mar Pollut Bull 162:111820. https://doi.org/10.1016/j.marpolbul.2020. 111820

Song X, Wu X, Song X, Shi C, Zhang Z (2021) Sorption and desorption of petroleum hydrocarbons on biodegradable and nondegradable microplastics. Chemosphere 273:128553. https://doi.org/ 10.1016/j.chemosphere.2020.128553

Sun J, Dai X, Wang X, van Loosdrecht MCM, Ni B-J (2019) Microplastics in wastewater treatment plants: detection, occurrence and removal. Water Res 152:21-37. https://doi.org/10.1016/j.watres. 2018.12.050
Tziourrou P, Bourikas K, Karapanagioti HK (2020) Measuring the size and the charge of microplastics in aqueous suspensions with and without microorganisms using a zeta-sizer meter. Springer Water 250-254. https://doi.org/10.1007/978-3-030-45909-3_39

Wagstaff A, Lawton LA, Petrie B (2021) Polyamide microplastics in wastewater as vectors of cationic pharmaceutical drugs. Chemosphere 288:132578. https://doi.org/10.1016/j.chemosphere.2021. 132578

Wang Z, Zhao J, Song L, Mashayekhi H, Chefetz B, Xing B (2011) Adsorption and desorption of phenanthrene on carbon nanotubes in simulated gastrointestinal fluids. Environ Sci Technol 45(14):6018-6024. https://doi.org/10.1021/es200790x

Wang H, Xi H, Xu L, Jin M, Zhao W, Liu H (2021) Ecotoxicological effects, environmental fate and risks of pharmaceutical and personal care products in the water environment: a review. Sci Total Environ 788:147819. https://doi.org/10.1016/j.scitotenv. 2021.147819

Whitlock SE, Pereira MG, Shore RF, Lane J, Arnold KE (2018) Environmentally relevant exposure to an antidepressant alters courtship behaviours in a songbird. Chemosphere 211:17-24. https:// doi.org/10.1016/j.chemosphere.2018.07.074

Publisher's Note Springer Nature remains neutral with regard to jurisdictional claims in published maps and institutional affiliations. 